\title{
PEEPING THROUGH THE WINDOWS OF THE WEALTHY
}

FREDERIC COPLE JAHER, ed. The Rich, the Well Born, and the Powerful: Elites and Upper Classes in History. Urbana: University of Illinois Press, 1973. Pp. 379, tables, bibliography. \$15.00.

EDWARD PESSEN. Riches, Class, and Power Before the Civil War. Lexington, Mass.; Toronto; London: D.C. Heath and Company, 1973. Pp. 378 , tables, maps, illus., appendices, bibliography, index.

"But he who greatly excels in beauty, strength, birth or wealth," wrote Aristotle, "or on the other hand who is very poor, or very weak, or very much disgraced, finds it difficult to follow rational principle. Of these two the one sort grow into violent and great criminals, the other into rogues and petty rascals" (Politics, IV, 1). The crafty old codger knew that the notion of a superior class only had meaning in relationship to other classes and to the particular structure in which the superior class was embedded. Frederic Cople Jaher and Edward Pessen, on the other hand, choose to follow only those who excel in beauty, strength, birth, and, especially, wealth. (By Aristotle's dictum, they thereby choose to follow "the violent and great criminals" as well, but about that side of things Jaher and Pessen say very little.) In pursuing the history of elites abstracted from class structures and removed from systematic comparisons, they impoverish our understanding of the processes which bring elites into being, and which keep them in place. Although the majority of the groups analyzed in the two books are elite by virtue of their relationships to particular cities, at the end we know little more about those cities than when we began.

Pessen has the greater excuse. He undertook his studies of New York City, Brooklyn, Boston, and Philadelphia not to clarify the experiences of those individual places but verify an argument about rich men in America as a whole. Jaher has no excuse at all. The halfheartedness of his 
introduction to the disparate essays in his book suggests he knows it; instead of identifying general conclusions, interesting disagreements, or recurrent difficulties, the introduction resorts to a series of wishy-washy taxonomies concerning the themes and methods of the articles. It even quavers when confronted with the problem of defining the "elites" and "upper classes" of the book's very title. "The varied categories that integrate these essays," it seems, "do not coalesce into a general conception of the upper strata" (p. 5). Amen.

Jaher's book appears to have grown from the seminars and colloquia of historians based at the University of Illinois around 1970. In approximate chronological order, we encounter elitism and democracy in classical Athens (Robin Seager), the aristocracy of the Roman Republic (Richard E. Mitchell), charity and the defense of urban elites in the Italian communes (Richard C. Trexler), politics and community in Elizabethan London (Frank F. Foster), the Rumanian Uniate hierarchy (Keith Hitchins), an eighteenth-century Russian view of bureaucracy and patronage (David L. Ransel), the Briansk Company in Tsarist Russia (John P. McKay), the survival of the Victorian aristocracy (Walter L. Arnstein), high society in nineteenth-century New York (Frederic Cople Jaher), metropolitan elites in the Midwest (Richard Jensen), the Chilean upper class from 1931 to 1933 (Paul W. Drake), and the New Deal intellectual (Thomas A. Krueger and William Glidden).

Taken individually, a number of the items are useful, interesting, even illuminating. For example, Trexler shows us how careful a distinction the Italian communes made between impoverished aristocrats and miserable plebeians, and how much of what appears at first view to be general charitable activity was actually directed to the "shamed poor"-skidding families from the elite. Again, Arnstein documents the tenacity of the British aristocracy through a nineteenth century of reform bills and massive industrialization, and proposes to locate the aristocracy's real loss of power around World War I. The bulk of the papers however, are rather less sure of their arguments, and therefore more purely descriptive. That is true, for example, of Ransel's use of an epistolary manual to document the importance of patronage in eighteenth-century Russia, Jaher's portrayal of fin-de-siècle New York's "beautiful people," and Jensen's expounding of computerized procedures for collective biography-as applied to a sample of men drawn from various sorts of Who's Who for Chicago, St. Louis, Detroit, Wichita, and Minnesota as a whole between 1907 and 1929.

Jensen comes across as enthusiastic about the returns from collective biography: "If the historian wants to discuss urban elites on the basis of 
more than a handful of remarkable cases, he will have to adopt a quantitative research strategy equal to the exigencies of dealing with great masses of data" (p. 288). One would therefore like to hear Jensen's reply to the stinging indictment that Krueger and Glidden, themselves collective biographers of New Deal intellectuals, apply to collective biography: "it tends to convey a spurious sense of precision when in fact it relies on ambiguous and overlapping categories, and it generates a false sense of explanatory power when it accounts, by itself, for no more than traditional narrative history" (p. 341). Since most of the book's essays employ some version, loose or rigorous, of collective biography, editor Jaher's failure to weigh the method's merits and demerits, to survey the divergent orientations of his authors thereto, or to state what standard, important historical problems the collective biography of elites can solve robs a book which by definition had no substantive coherence of the modest methodological coherence it might have attained.

By contrast, Edward Pessen's Riches, Class, and Power is nothing if not methodologically and substantively coherent. The method is the collective biography of very rich people in four nineteenth-century cities: New York, Brooklyn, Boston, and Philadelphia. The substance is largely negative; Jacksonian America did not, in Pessen's view, open up the elite to men of humble origin.

In addition to that main negative argument, Pessen provides detailed descriptions of the life styles, residential patterns, social ties, and political positions of the very wealthy in his four cities. The essential evidence takes the form of biographies of all persons whose visible wealth stood above some critical level at some point from 1828 to 1848 . Unfortunately, Pessen does not specify the minimum; nor do his tables or appendices state the numbers of persons on which the various percentage distributions are based. The lists of rich people at the end of the book suggest that he dealt with 200 to 300 persons in New York, about 70 in Brooklyn, close to 400 in Philadelphia, and 100 to 200 in Boston. Once tax rolls or (in the case of Philadelphia) a contemporary listing of rich people provided the crucial names, Pessen went to numerous other sources: private papers, genealogies, diaries, biographical dictionaries, pamphlets, published biographies, and so on. Peeping through the windows of the wealthy, he assembled his own picture of who they were and how they lived.

Among the very rich of those four cities, those who had any occupation were most likely to be merchants. They were likely to have inherited much of their wealth: "The urban rich of the antebellum era appeared to be successful above all in inheriting wealth and status that contributed 
significantly to their material fortunes" (p. 128). They were extensively connected with each other through intermarriage, common residence, and mutual entertainment. The diary of Philip Hone, one-time mayor of New York City, yields the crumbs from hundreds of dinner parties, and secretes the following statistic: "Better than 80 per cent of the more than five hundred New York City residents who dined or socialized with Hone during the 25-year period in which he recorded such data (1826 to 1851) were among the wealthiest 1 per cent of the city" (p. 237). Of such trivia we receive an abundance.

Whether or not he intends it, in fact, Pessen offers us a repugnant portrait of the rich. They are self-important, self-segregated, selfperpetuating snobs who spend much of their time in a round of display and idle entertainment. They populate the boards of civic associations, the high offices of city government and the managements of their family firms. As a result, they presumably wield great power. But, aside from their adornment of the Society of Promoting Religion and Learning in New York State, the Infirmary for the Relief of Poor Persons Laboring under Hernia or Rupture, or the Massachusetts Charitable Eye and Ear Infirmary, Pessen provides little evidence of their impact on the lives of their fellow-citizens. Or of their concern about that impact.

We face one of the severest limits of collective biography. It can tell us much about who the people in different positions were and where they came from. It can tell us something about how they were connected to each other. But it has relatively little to contribute to our understanding of the actual use of power, position, wealth, and connection, as well as the impact of that power, position, wealth, and connection on the rest of the world. Sir Lewis Namier (1961: 40) sidestepped that problem by treating British policy as a natural emanation of British character as filtered through Britain's governmental system and its personnel: "In the end statesmen hardly ever act except under pressure of 'circumstances', which means of mass movements and of the mental climate in their own circles." At least Namier had a clear vision of the decision-making system through which the parliamentarians whose biographies he lovingly compiled made their influence felt. Pessen, in contrast, concentrates so exclusively on the origins and characteristics of the rich that he has no means of assaying their relations to other classes or their place in the system as a whole. Indeed, he avoids even the obvious device of making systematic comparisons among his four cities and their elites.

And why? The irony is that when Pessen arrives at the brink of systematic use of his evidence, his own skepticism about the value of his 
enormous efforts turns him back. "It would be possible," he observes at one point, "to portray by a graph the number of men engaged in two or three occupations; but the impossibility of ascertaining the dimensions or proportions of such involvements suggests the value-at least in this case-of a word-picture rather than a statistical one. If the evidence is incomplete, it is nevertheless useful and suggestive" (p. 46). Thus, time and time again we find ourselves in limbo, halfway between a full, rigorous presentation of the evidence and an impressionistic display of selected portraits. The arguments gain their implicit weight from the large numbers of biographies under examination, yet we rarely get to do any examining of the evidence for ourselves.

Neither Pessen nor Jaher, then, provides us with a viable model for urban history. The failure of the two books as urban history is not due to the inherent complexity of the problem, although that complexity is great. Lawrence Stone's Crisis of the Aristocracy (1965) and Family and Fortune (1973) show that it is possible to write brilliant social history focused on ruling classes. Their failure is due to their neglect of Aristotle's teaching: begin with the structure of the community, locate your classes within it, make systematic comparisons of classes and communities. Reason, in short, from the variables rather than the constants. The teaching was there in plain sight; the first sentence of the first essay in Jaher's collection, by Seager, runs: "In Politics Aristotle repeatedly draws a distinction between the men of note in community, hoi gnorimoi, and the masses" (p. 7). What is more, Aristotle repeatedly states his analysis in the form of a comparison among the constitutions of Athens, Sparta, and other cities. Would that urban historians could discard their particularism, and heed the ancient teachings of Aristotle.

\author{
-Charles Tilly \\ University of Michigan
}

\title{
REFERENCES
}

NAMIER, L. (1961) England in the Age of the American Revolution. New York: St. Martin.

STONE, L. (1973) Family and fortune: Studies in Aristocratic Finance in the

Sixteenth and Seventeenth Centuries. London: Oxford Univ. Press.

_... (1965) Crisis of the Aristocracy 1558-1641. London: Oxford Univ. Press.

Charles Tilly is Professor of Sociology and History at the University of Michigan. His latest book is The Rebellious Century 1830-1930 (1975), with Louise Tilly and Richard Tilly. 